familiar Authorized Version is to change 'Then cometh the end' (oer. 24) into 'Then at the end', and to alter the punctuation' by putting a semi-colon instead of a full-stop at the end of ver. 23 , and commas instead of full-stops at the ends of $v v .24,25$, and 26 .

F. C. BurkitT.

\title{
TEXTUAL CRITICISM OF THE OLD TESTAMENT
}

THE subject treated in my note in the January number of the Journal is of so great importance that I am glad that Mr McLean's rejoinder in the April number gives me the opportunity of returning to it. I think there is a difference as to the principles of textual criticism between $\mathrm{Mr} \mathrm{M}^{\circ} \mathrm{Lean}$ and myself, and I should like to state quite clearly what my own principles are.

There is, indeed, nothing new in them; they are familiar to every student of the New Testament, but they apply (I believe) equally well to the Old.

(i) In the case which I discussed in January (Ps. xcrii I I) two of these principles are specially applicable. They are (1) Parallel passages are specially liable to corruption by assimilation; (2) The difficult reading is generally to be preferred to the easier. I need not say that both these principles are amply illustrated in the text (e.g.) of the Synoptic Gospels. The state of the Lucan text of the Lord's Prayer illustrates (I); while several rugged passages in the Second Gospel illustrate (2).

But are not these principles to be applied also to the textual criticism of the Psalms? I say without hesitation that it is just, simply just, to keep in mind in the study of the text of the O.T. the danger of textual assimilation of parallel passages. Here is an undeniable case of a near coincidence in language which a scribe would be tempted consciously or unconsciously to make more complete.

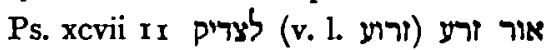

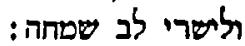 \\ Ps. cxii 4 זרח ברשך אור לישרים}

The first of these two parallel passages is afflicted with a (presumed) various reading (m) which in fact coincides with the reading of the second. When such a case occurs in the New Testament, critics give careful consideration to the possibility that an attempt has been made to assimilate one passage to the other.

The second principle, that of giving preference generally to the harder reading, also applies to Ps. xcvii ir. I think -no one will deng VOL. XVII. 
that אור. זרע is the harder reading, which a scribe or a translator would be tempted to change into the dangerously easy emendation On the other hand, the harder reading is in accordance with Hebrew thought ': 'Light is sown and gladness (harvest' gladness ') for the upright in heart.'

The corollary may be added that while it is easy to see a reason why ורע should be corrupted into in iרח in ith אור standing next to it!) should be corrupted into זרע.

(ii) When Mr McLean goes on to criticize my suggestion about the original reading of the Peshitta he overlooks the existence of the parallel passage, and also the existence of the Syro-Hexaplar. I need not defend at length a view which was put forward as a suggestion, only, but it is at least worthy of something better than ridicule. (I) D, is an actual Syriac rendering used in this passage, not a fancy of my own brain ; (2) it could easily be confused by a scribe reading a worn MS with w? the present reading of the Peshitta, especially since (3) the easy reading 2 already existed in the parallel passage (Ps. cxii 4) to help the scribe to go wrong.

(iii) The Targum gives דנח ומיטמר, a double rendering, the first word corresponding to iר the second to himself with citing ד second word altogether. This, I contend, is unfair, but Mr MoLean would justify Wellhausen by maintaining that can only be 'due to revision of the more primitive Targum-text on the basis of the later Massoretic'. I think that Mr M०Lean has been misled by the mere order of the words, which is by no means decisive as to the priority in time of the first word. Once more it is necessary to remember the disturbing influence of the parallel passage. The Targumist is more than a word-for-word translator; he adds a touch of comment from time to time. Here he remembers two slightly varying promises or assurances and he reconciles them, blending them into one. 'For the righteous and upright', he says, 'light is sometimes spreading its rays, sometimes hiding them', but let the righteous none the less 'rejoice in the Word of JeHovar'. I hope it is not necessary to assure Mr M०Lean that I am 'serious' in thinking that the double rendering of the Targum is due to the double reading of the Hebrew, one in Ps. xcvii 11 , the other in Ps. cxii 4.

(iv) In one respect I acknowledge that Mr McLean has caught me. I did not realize the fact that Wellhausen in his critical edition of the Book of Psalms nowkere gives more than the evidence for readings

1 See Jowmal, p. I 56.

- The Heb. החDO is a common word, but it is not without significance that it is applied to harust joy (Isa ix 2 ; xvi ro). 
differing from $M T$. It is an unpleasant shock to one's feeling of what is due to scholarship to realize that this is Wellhausen's method. To my mind few tasks are more difficult than the task of stating fairly one. side only of the evidence in a textual problem. When one side only is stated, the statement can hardly fail to give a false impression. It is often difficult to extract a simple Yes or $N o$ from a textual authority, particularly if that authority be a version. Wellhausen's curt note with its ' $Z \mathbb{Z} \mathbb{C} E$ ' certainly gives one the impression that there is practically no evidence to be alleged for the MT of Ps. xcrii ir (beyond the MT itself), and that the evidence for $n$, the supposed reading of the.LXX, is overwhelming. But this is a false impression. The witness of ', certainly here in the Psalter, is more probably an echo of efr than a piece of independent evidence. T's reading, zuhich Wellhausen has mis-stated, tells at least as much in favour of MT as against it. $\$$ (on comparison with the parallel place) lies under a textual doubt, slight perhaps, but real, and not to be simply blown aside. Lastly, as regards of itself, it must be remembered that the rendering dućtechev is no conclusive proof that the Seventy found the reading in the Hebrew copy or copies from which they translated. The existence of a parallel passage has influenced the Alexandrine translators in other places, notably in one discussed briefly below (Zech. i 8). That the Seventy themselves felt that Ps. xcvii I I and Ps. cxii 4 are kindred passages is sufficiently shewn by their renderings :

(a)

(Ps. xcvii $\mathrm{I}$; Swete following B).

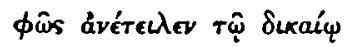

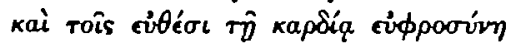

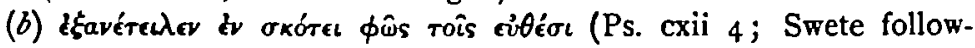
ing $\aleph$ ).

In the light of this close parallelism it cannot safely be asserted that the LXX read $m$ in Ps. xcrii Ir. If they had had before them the reading found in all but all of our Hebrew MSS (an entirely probable assumption), they would nevertheless have been sorely tempted to emend this harder reading (ורע) into the easier reading of the parallel passage. Their business was to make a popular and readable translation.

A similar case of the corrupting influence of a parallel passage is found in Zech. i 8, 10, 11 . Here Wellhausen does not go with LXX, at least in the book before me (Skizzen, funftes Heft, r 892, §39). The prophet narrates eight visions, the first (i $7 \mathrm{ff}$ ) and the eighth (vi $\mathrm{I}-8$ ) being somewhat similar in imagery. In the first a mysterious horseman, behind whom were horses of different colours; stood 'among the myrtle trees' (הרסים). In the eighth four chariots drawn by horses of different 
colours, representing the winds of heaven, were seen coming out 'from: between two mountains' (דרים). The two different notes of place are thus kept distinct for the two visions in MT, but the distinction is obliterated in the LXX. In the Greek the mysterious horseman of the

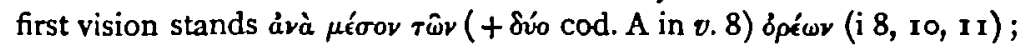

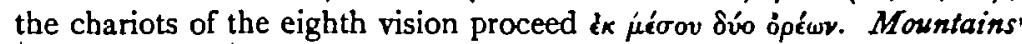
are more common than myrtles in the imagery of $O . T$. visions, and the Hebrew equivalent of the former occurs some hundred times as against three occurrences of the latter in O.T. So the Greek translators again follow the line of least resistance. They submit to the disturbing influence of a parallel passage, and once more they give their preference to the more 'ordinary' reading.

Looking back over the points of our discussion I feel that I havevery little to withdraw : that little is the assumption that Wellhausen's statement of the evidence was intended to be in some sense complete. I learn from $\mathrm{Mr}$ McLean that it was intended to be ex parte. Looking back again at my own presentation of the textual facts (JouRNAL, p. $15^{6}$ ) I see nothing to change, though I should be glad to add $\mathfrak{I}$ (for Jerome's Psalierium iuxta Heb.) within brackets to the authorities quoted for חา. But the brackets must not be omitted, for the reading is word for word that of the Gallican Psalter, which is only a revision of an Old Latin version of the LXX. Jerome, therefore, may be only echoing the Serenty in this passage.

$\mathrm{Mr} \mathrm{M}^{\circ} \mathrm{L}$ ean and I are 'out', I gather, on three matters of principle. I hold ( $\mathrm{I}$ ) that in the O.T. as in the N.T. the danger of corruption from a parallel passage is very great; (2) that the prima facie case is in favour of a harder reading; (3) that the reading of the MT counts as a reading, while prima facie the 'reading' of the LXX is only an interpretation or an emendation. Interpreters are more likely to change what they see than scribes, so evidence is needed to raise a rendering of the Greek to the position of a witness to a various reading of the underlying Hebrew text. Mere suspicion of the MT cannot be counted as evidence. Mr MoLean passes very lightly over these considerations. Finally we differ on a matter of degree. By all means let the evidence (or supposed evidence) of the LXX be received and tested. But let the facts as to the origin of the version and its transmission in early. days be duly weighed. Something can be learned from an ignorant witness and even from one who has been 'handled' by an Origen or a' Lucian, but his evidence must be severely sifted. The bulk of it will dwindle sorely in the process, and we may be thankful if out of ten passages of the MT which seem to us to need emendation, the LXX gives us trustworthy help in one.

W. EMrRy BARNES, 